\title{
Asepsis in Operative Dentistry and Endodontics
}

\author{
Priyanka Sriraman, Prasanna Neelakantan
}

Saveetha Dental College, Saveetha University, Chennai, India

\begin{tabular}{l} 
Article Info \\
\hline Article history: \\
Received Dec 6, 2013 \\
Revised Jan 20, 2014 \\
Accepted Feb 26, 2014 \\
\hline
\end{tabular}

\section{Keyword:}

Disinfection

Sterilization

Cross infection

Prions

Barrier

Biofilms

Infection control

\begin{abstract}
Operative (conservative) dentistry and endodontics are specialties of dentistry where the operator is exposed to various infectious agents either via contact with infected tissues, fluids or aerosol. The potential for cross infection to happen at the dental office is great and every dentist must have a thorough knowledge of the concepts of sterilization and disinfection. Disposables should be used wherever possible. Furthermore, the water supply to the dental chair units and water outlets can house biofilms of microbes and should be considered as possible sources of infection. This review discusses the importance of following strict aseptic protocols from the perspective of operative dentistry and endodontics.
\end{abstract}

Copyright @ 2014 Institute of Advanced Engineering and Science. All rights reserved.

\section{Corresponding Author:}

Prasanna Neelakantan,

Department of Conservative Dentistry and Endodontics,

Saveetha University,

162 Poonamallee High Road, Velappanchavadi, Chennai - 600077, Tamil Nadu, India.

Email; prasanna_neelakantan@yahoo.com

\section{INTRODUCTION}

Dental professionals are exposed to a variety of micro-organisms present in the blood and saliva of patients, making infection control an issue of utmost importance. Asepsis is the state of being free from disease causing contaminants such as bacteria, viruses, fungi, parasites in addition to preventing contact with micro-organisms. The main goal of infection control is either to reduce or eliminate the chances of microbes getting transferred between the patients, doctors and the dental auxiliaries.

The basic principles of asepsis and infection control are: use of gloves, protective eye wear, plastic aprons, use of properly disinfected and sterilized instruments, proper disposal of sharps and infected waste material. In endodontics, a disease can be transmitted from patient to dentist or from dentist to patients or between patients through cross contamination. For transmission of the infection- a pathogenic organism should be present, Mode of transmission could be through direct contact between the individuals, or indirect contact through unsterilized instruments or by salivary droplets/aerosol spray, route of entry of microorganisms can be inhaled, injected, implanted or splashed on the skin or mucosa, susceptibility of host may be influenced by reduced host immunity.

\section{RESEARCH METHOD}

The paper is based on systematic literature review. 


\section{RESULTS AND ANALYSIS}

The dental environment, especially the field of restorative dentistry and endodontics provides several factors that can behave as a source of infection transmission. Instruments, saliva, aerosol are possible modes of transmission of infection. Contaminated dental instruments are the most important route in this regard [1]. Since diseases such as HIV and Hepatitis B get transmitted through infected instruments and materials [2], sterilization and disinfection is of utmost importance. This review discusses the methods of achieving asepsis in endodontics. The need for sterilization and disinfection of the armamentarium used in operative dentistry and endodontics, possible routes and modes of transmission of infection, barrier protection and operating field disinfection have been highlighted.

\section{PRIONS}

Transmissible spongiform encephalopathies also known as prion-related diseases are group of fatal neuro-degenerative disorders associated with the modification of prion protein (PrP). Prions are transmissible particles that do not contain nucleic acid but contain a modified protein (PrP sc). A normal cellular PrP gets converted to PrPsc through post-translational processes during which it receives a high B-sheet content. The most notable prion diseases are the bovine spongiform encephalopathies (BSE), scrapie of sheep, and Creutzfeldt-Jakob disease (CJD) of humans. The first documented iatrogenic CJD was in 1977 due to reuse of contaminated neurosurgical instruments [3]. Decontamination of used instruments seem to have no effects on these agents [4] . Studies have shown that autoclaving is effective against the agents [5]. Since diagnostic aids are not available, detecting carriers is almost impossible.

Endodontic files are in direct contact with the blood and tissue during treatment. Studies have shown that intra-dental route could be a source of transmission of the disease [6],[7]. Since endodontic instruments are reused by many practitioners, they could be a source of cross contamination [8]. Several endodontic societies across the globe have suggested the single use of root canal files and reamers to realize this goal.

\section{CONTAMINATION AND CROSS-CONTAMINATION}

All patients must be considered as infectious carriers and the universal precautions should be used for all of them [9]. However infection controls in developing countries are poorly followed [10]. The term aerosol and splatter was first described by Micik and colleagues. Aerosols are particles which are less than 50 micrometer in diameter and are airborne before settling down on any surface. Due to their minute structure, they have the ability to settle in the tiny spaces and pores present on the skin surface and the lungs when inhaled. Splatter on the other hand is described as particles which are more than 50 micrometer in diameter [11],[12]. Aerosol and droplets of blood and saliva may allow transmission of diseases such as measles, tuberculosis, SARS, hepatitis, AIDS [13]-[15]. Use of $0.01 \%$ chlorhexidine or essential oil mouth wash 60 seconds prior to the start of dental procedure has shown to bring about a reduction in the amount of bacterial count [16],[17].

Studies have shown that there is a higher concentration of serum antigen and antibodies for Hepatitis B [18], Hepatitis C [19], and Legionella species [20] in dentists than in the general population. An increased prevalence of respiratory infections has also been noticed owing to aerosols. Candida albicans, an yeast, is present in the oral cavity of one third of the adult population. It is an opportunistic pathogen. Theoretically it is possible for it to spread from the patient to the health care provider, but chances are less unless the health care provider is immunocompromised. Other infections like Streptococcus pyogenes, Varicella zoster can also be transmitted [21].

\section{STERILIZATION AND DISINFECTION}

Sterilization is the process of destroying all the micro-organism from an article or surface including spores. Disinfection is usually less lethal to the micro-organisms as compared to sterilization. Items to be sterilized or disinfected are categorized as:

Critical items: These include any instrument exposed to blood or body fluid contact. Surgical instruments, forceps, burs, periodontal knife are examples of this category of items. In restorative dentistry and endodontics, all hand and rotary instruments, root canal files, reamers are critical items that need to be sterilized.

Non critical items: These are items that do not contact body fluids or any break in soft tissue. Radiographs, blood pressure cuffs have to be disinfected and sterilized. In endodontics, the items that 
do not contact the root canal space ie., glass slab, cement spatula need to be disinfected. Absorbent paper points and root canal filling materials like silver points, gutta-percha points and Resilon points should be disinfected before use.

Re-usable or semi critical items: plastic impression trays, amalgam carriers. These can be disinfected alone.

Sterilization can be achieved by: moist heat (autoclave), dry heat (hot air oven, glass bead sterilizer), chemical sterilization, ethylene oxide sterilization. Disinfection can be achieved by short term immersion in $5.25 \%$ sodium hypochlorite, glutaraldehydes, providone iodine diluted in water or halogenated phenol, chlorhexidine or peracetic acid.

Studies have shown that instruments used in endodontics, such as files and reamers may carry infected organism or their breakdown products. These residues may be present even after washing and can retain their potency to induce infections [22]. The safest method to ensure that there are no residual infected micro-organism is through incineration [23] . The instruments should be mechanically cleaned before they are subjected to sterilization to inactivate any debris that can be visualized. Ultrasonic cleaning reduces the chances of direct handling of the instruments (thereby ensuring operator safety) and also much more efficient than manual cleaning [24]-[26].

The use of enzymes in presoaking prior to cleaning has been recommended. While some studies have shown that pre-soaking the instruments in an enzymatic material increases the effectiveness of the cleaning [27]. But in contrast, Aasim et al. [28] showed that pre soaking had no significant effect on the cleanliness of the instruments prior to ultrasonic cleaning. However, it may be logical to assume that the enzyme could potentially help in disintegrating the active infectious breakdown components of microbes into inactive components. The process of sterilization may be discussed in terms of a decontamination cycle that involves presoaking the instruments, cleaning, drying and visualization, packaging, sterilization and storage. Only steam sterilization (autoclaving) can result in complete sterility of instruments [29].

Several studies have assessed the role of autoclaving on the properties of stainless steel and nickel titanium endodontic instruments. While some studies demonstrate a reduction in the cutting efficiency of these instruments, some papers show otherwise. Nevertheless, the reduction in cutting efficiency was not significant and hence the clinical impact may be deemed insignificant [30],[31].

Root canal instruments should also be subjected to chair-side sterilization. This is advocated to prevent cross contamination between root canals or teeth in the same patient. For example, in a lower molar tooth, one of the canals could be infected while one canal could be uninfected. Transmission of infected material to the uninfected canal can possibly reduce the chances of success of root canal treatment. For chairside decontamination of the instruments, wiping the instruments with $2 \times 2$ inch gauze soaked in isoproyl alcohol showed 90\% reduction even though sterilization wasn’t achieved [32]. Glass bead sterilizers and hot salt sterilizers have been recommended for this purpose. Recently studies are being conducted on the ability of LASERs to sterilize instruments. Hooks et al. demonstrated that carbon dioxide LASER brought about $100 \%$ reduction of spores from contaminated root canal reamers [33]. When comparing three LASERscarbon dioxide, Argon and Nd:YAG, Powell et al showed that all three lasers were able to sterilize instruments but argon required the lowest energy (1 watt for 120 sec.) as compared to the other two which required higher energies [34].

\section{DISINFECTION OF WATER LINES}

A common water supply for the hand piece, scaler and air water syringe is usually present and is known as the dental unit water lines (DUWL). Black was the first to report the contamination of the water supply in 1963 [35]. Studies show that this water supply is contaminated with biofilms of gram negative bacteria and gram positive cocci [36]. Also biofilm formation in these water lines has been noticed for past 40 years [37]. The Centre for Disease Control and Prevention (CDC) has given specific guidelines for asepsis of water lines. Portable water should be used for general applications and sterile water for any surgical procedures [38].

The handpieces (airotor and micromotor) must be cleaned and sterilized between each patient. The hand piece and water line should be flushed for about 30 seconds into a sink or a container before removing for sterilization. The tips of air-water syringes must be sterilized between each patient. At the beginning of the treatment day, all water lines should be flushed for about 5 mins to reduce microbial content of the water lines.

Filters may be used near the handpiece, which may act as a physical barrier and prevent the microorganisms to pass through. These filters can also be designed and placed in such a way that the water is 
filtered before entering the dental unit. Despite the fact that filters can purify water to a certain extent they cannot reduce bacterial counts [39]. In practice, one may consider it prudent to add chemical disinfectants to filters or use filters that contain antibacterial substances like iodine. The chemical disinfectants that may be used to achieve this goal are glutaraldehyde, hydrogen peroxide, sodium hypochloride, isopropyl alcohol, silver salts and chloramine $\mathrm{T}$ [39]. Chemical disinfectants if used, should be left to remain in the lines overnight and then should be flushed next morning. In addition to destroying the bacteria present in the DUWL, the disinfectant that is used should also be able to prevent or atleast reduce bacterial re-population. Although glutaraldehyde is an effective disinfectant, sodium hypochlorite has been shown to be more effective in preventing re-population of microorganisms [39]. Meiller et al demonstrated that sodium hypochlorite, glutaraldehyde and $15.3 \%$ isopropanol were effective in reducing the recurrence of microbial growth in the DUWL [40].

Back flow from saliva ejector tubes into the patient's mouth may be a source of cross contamination. This could expose the mucosa of the patient to the saliva or blood of another patient. This back flow usually occurs when the patients form a seal by closing the lip around the saliva ejector seal. Hence dental units should include protective valves in the handpiece to prevent patients' saliva entering the unit tubing. Also contamination is possible due to leakage from the hose due to loosening during use. Hence replacement of these hose connectors should be done periodically [41].

\section{DISINFECTION OF WATER LINES}

Surface barriers are easier way to prevent cross contamination. Surfaces to be barrier-protected are dental unit light handles, light cure units, head rest, arm rest, high speed handpiece coupling and hose, air water syringe and hose, saliva ejector and hose, radiography unit handles, cones and controls, endodontic motors and handpieces, apex locators, thermoplasticized obturation units. Many preformed barriers are available and are specific to the item to be protected. Usually plastic cling wrap or food wraps are used as inexpensive alternatives. They must be changed in between each patient.

\section{Rubber dam}

Rubber dam was first introduced by Dr. S.C. Barnum in 1864. The use of rubber dam in endodontic treatment helps in control of cross infection, protection and improving treatment efficiency. Air turbines might result in the formation of aerosol or droplets contaminated with saliva and blood. The use of rubber dam will result in decreased amount of cross contamination of pathogens during dental procedures [14],[15],[42],[43]. It also protects the patients from aspiration of the instruments, medicaments and irrigating materials [44],[45]. It also protects the soft tissues such as gingiva and lip from iatrogenic trauma by the instruments [45].

Studies have showed that practitioners who place rubber dams are more likely to use a higher quantity and concentration of sodium hypochlorite than non-users who prefer saline or solutions such as local anaesthetics for irrigation purpose. The advantages of this are obvious. Sodium hypochlorite is the material of choice for root canal irrigation as it is the only agent capable of disintegrating a biofilm apart from its antimicrobial action. It is also capable of dissolving vital and infected tissue. The use of saline or other irrigating solutions do not offer these advantages [46]-[48]. Studies have showed that the outcome of endodontic retreatment was better in cases isolated with rubber dam compared to those used with conventional methods such as cotton rolls [49]. Also since mishaps are quite common in endodontic treatment, studies have shown that rubber dam use has reduced the incidence of accidents [50].

\section{CONCLUSIONS}

The dental operatory is a potential source of infection and cross-infection. Proper barrier protection and asepsis achieved via sterilization and disinfection are of paramount importance to protect the dental personnel and patients. All dentists must be educated and trained in these protocols to provide better care to patients.

\section{REFERENCES}

[1] Gurevich I, Dubin R, Cunha BA. "Dental instrument and device sterilization and disinfection practices”, J. Hosp Infect, Vol/Issue: 32(4). Pp. 295-304, 1996.

[2] Sobayo EI. "Nursing aspects of infection control in developing countries”, J. Hosp Infect, 18 Suppl A. Pp. 388-91, 1991. 
[3] Bernoulli C, Siegfried J, Baumgartner G, Regli F, Rabinowicz T, Gajdusek DC, Gibbs CJ Jr. "Danger of accidental person-to-person transmission of Creutzfeldt-Jakob disease by surgery”, Lancet., Vol. 1(8009). Pp. 478-9, 1997.

[4] Taylor DM. "Inactivation of transmissible degenerative encephalopathy agents: A review", Vet J., Vol/Issue: 159(1). Pp. 10-7, 2000.

[5] Fichet G, Comoy E, Duval C, Antloga K, Dehen C, Charbonnier A, McDonnell G, Brown P, Lasmezas CI, Deslys JP. Novel methods for disinfection of prion-contaminated medical devices. Lancet.2004 Aug7-13; 364(9433):521-6

[6] Ingrosso L, Pisani F, Pocchiari M. “Transmission of the 263k scrapie strain by the dental route”, J Gen Virol, Vol. 80. Pp. 3043-7, 1999.

[7] Morrison A and Conrod S. "Dental burs and endodontic files: Are routine sterilization procedures effective?”, $J$ Can Dent Assoc, Vol. 75. Pp. 39a-d, 2009.

[8] Bourvis N, Boelle PY, Cesbron JY, Valleron AJ. "Risk assessment of transmission of sporadic Creutzfeldt-Jakob disease in endodontic practice in absence of adequate prion inactivation”, PLoS One, Vol/Issue: 2(12). Pp. e1330, 2007.

[9] Recommended infection-control practices for dentistry. "Centers for disease control and prevention", MMWR Recomm Rep, Vol. 42(RR-8). Pp. 1-12, 1993.

[10] Al-Omari MA, Al-Dwairi ZN. "Compliance with infection control programs in private dental clinics in Jordan”, $J$ Dent Educ, Vol/Issue: 69(6). Pp. 693-8, 2005.

[11] Micik RE, Miller RL, Mazzarella MA, Ryge G. "Studies on dental aerobiology. I. Bacterial aerosols generated during dental procedures”, J Den Res, Vol/Issue: 48(1). Pp. 49-56, 1969.

[12] Miller RL, Micik RE, Abel C, Ryge G. "Studies on dental aerobiology. II. Microbial splatter discharged from the oral cavity of dental patients”, J Dent Res, Vol/Issue: 50(3). Pp. 621-5, 1971.

[13] Wong TW, Lee CK, Tam W et al. "Cluster of SARS among medical students exposed to single patient, Hong Kong”, Emerg infect Dis, Vol/Issue: 10(2). Pp. 269-76, 2004.

[14] Forrest WR, Perez RS. "The rubber dam as a surgical drape: protection against AIDS and hepatitis", Gen Dent, Vol/Issue: 37(3). Pp. 236-7, 1989.

[15] Harel SK, Molinari J. "Aerosols and splatter in dentistry. a brief review of the literature and infection control and implications”, J Am Dent Assoc, Vol/Issue: 135(4). Pp. 429-37, 2004.

[16] Logothetis DD, Martinez-Welles JM. "Reducing bacterial aerosol contamination with a chlorhexidine gluconate pre-rinse”, J Am Dent Assoc, Vol/Issue: 126(12). Pp. 1634-9, 1995.

[17] Fine DH, Korik I, Furgang D, Myers R, Olshan A, Barnett ML, Vincent J. “Assessing pre-procedural subgingival irrigation and rinsing with an antiseptic mouthrinse to reduce bacteremia”, J Am Dent Assoc, Vol/Issue: 127(5). Pp. 641-2,645-6, 1996.

[18] Mori M. "Status of viral hepatitis in the world community: its incidence among dentists and other dental personnel”, Int Dent J, Vol/Issue: 34(2). Pp. 115-21, 1984.

[19] Klein RS, Freeman K, Taylor PE, Stevens CE. "Occupational risk for hepatitis C virus infection among New York city dentist”, Lancet, Vol. 338(8782-8783). Pp. 1539-42, 1991.

[20] Reinthaler FF, Mascher F, Stunzner D. "Serological examinations for antibodies against Legionella species in dental personnel”, J Den Res, Vol/Issue: 67(6). Pp. 942-3, 1988

[21] Davies KJ, Herbert AM, Westmoreland D, Bagg J. "Seroepidemiological study of respiratory virus infections among dental surgeons”, Br Dent J, Vol/Issue: 176(7). Pp. 262-5, 1994.

[22] Gill DS, Tredwin CJ, Gill SK, Ironside JW. “The transmissible spongiform encephalopathies (prion diseases): a review for dental surgeons”, Int Dent J, Vol/Issue: 51(6). Pp. 439-46, 2001.

[23] Scully C, Smith AJ, Bagg J. "Prions and the human transmissible spongiform encephalopathies”, Dent Clin North Am, Vol/Issue: 47(3). Pp. 493-516, 2003.

[24] Ferreira Murgel CA, Walton RE, Rittman B, Pecora JD. “A comparison of techniques for cleaning endodontic files after usage: a quantitative scanning electron microscopic study”, J Endod, Vol/Issue: 16(5). Pp. 214-7, 1990.

[25] Palenik CJ. "Using ultrasonic cleaners to reduce exposure to bloodborne disease", J Mass Dent Soc, Vol/Issue: 42(3). Pp. 121-4, 1993.

[26] Cafruny WA, Brunick A, Nelson DM, Nelson RF. "Effectiveness of ultrasonic cleaning of dental instruments”, $A m$ J Dent, Vol/Issue: 8(3). Pp. 152-6, 1995.

[27] Sanchez E, Macdonald G. "Decontaminating dental instruments: testing the effectiveness of selected methods", $J$ Am Dent Assoc, Vol/Issue: 126(3). Pp. 359-62,364,366 passim, 1995.

[28] Aasim SA, Mellor AC, Qualtrough AJ. "The effect of pre-soaking and time in the ultrasonic cleanliness of sterilized endodontic files”, Int Endod J, Vol/Issue: 39(2). Pp. 143-9, 2006.

[29] Hurtt CA, Rossman LE. "The sterilization of endodontic hand files”, J Endod, Vol/Issue: 22(6). Pp. 321-2, 1996.

[30] Neal RG, Craig RG, Powers JM. "Effect of sterilization and irrigants on the cutting ability of stainless steel files", $J$ Endod, Vol/Issue: 9(3). Pp. 93-6, 1983.

[31] Mitchell BF, James GA, Nelson RC. “The effect of autoclave sterilization on endodontic files”, Oral Surg Oral Med Oral Pathol, Vol/Issue: 55(2). Pp. 204-7, 1983.

[32] Hubbard TM Jr, Smyth RN, Pelleu GB Jr, Tenca J. “Chairside decontamination of endodontic files”, Oral Surg Oral Med Oral Pathol, Vol/Issue: 40(1). Pp. 148-52, 1975.

[33] Hooks TW, Adrain JC, Gross A, Bernier WE. "Use of the carbon dioxide laser in sterilization of endodontic reamers”, Oral Surg Oral Med Oral Pathol, Vol/Issue: 49(3). Pp. 263-5, 1980.

[34] Powell GL, Whisenant BK. “Comparison of three lasers for dental instrument sterilization”, Lasers Surg Med, Vol/Issue: 11(1). Pp. 69-71, 1991. 
[35] Barbeau J, Gauthier C, Payment P. "Biofilms,infectious agents, and dental unit waterlines: a review”, Can J Microbiol, Vol/Issue: 44(11). Pp. 1019-28, 1998.

[36] Szymanska J. "Bacterial contamination of water in dental unit reservoirs", Ann Agric Environ Med, Vol/Issue: 14(1). Pp. 137-40, 2007.

[37] Szymanska J. "Biofilm and dental unit waterlines”, Ann Agric Environ Med, Vol/Issue: 10(2). Pp. 151-7, 2003.

[38] Guidelines for infection control in Dental Health-care settings.

[39] Monarca S, Garusi G, Gigola P, Spampinato L, Zani C, Sapelli PL. "Decontamination of dental unit waterlines using disinfectants and filters”, Minerva Stomatol, Vol/Issue: 51(10). Pp. 451-9, 2002.

[40] Meiller TF, Depaola LG, Kelley JI, Baqui AA, Turnq BF, Falkler WA. "Dental unit waterlines:biofilms, disinfection and recurrence”, J Am Dent Assoc, Vol/Issue: 130(1). Pp. 65-72, 1999.

[41] O’Donnell MJ, Tuttlebee CM, Falkiner FR, Coleman DC. "Bacterial contamination of dental chair units in a modern dental hospital caused by leakage from suction system hoses containing extensive biofilm”, $J$ Hosp Infect, Vol/Issue: 59(4). Pp. 348-60, 2005.

[42] Cochran MA, Miller CH, Sheldrake MA. "The efficacy of the rubber dam as a barrier to the spread of microorganisms during dental treatment”, J Am Dent Assoc, Vol/Issue: 119(1). Pp. 141-4, 1989.

[43] Samaranayake LP, Reid J, Evans D. "The efficacy of rubber dam isolation in reducing atmospheric bacterial contamination”, ASDC J Dent Child, Vol/Issue: 56(6). Pp. 442-4, 1989.

[44] Ingle JI, Walton RE, Malamed SF et al. Preparation for endodontic treatment In: Ingle JI, Bakland LK, eds.Endodontics, 5th edition Hamilyon: BC Decker Inc. Pp. 394-403, 2002.

[45] Glickmm GM, Pettiette MT. Preparation for treatment In: Cohen S, Hargreaves KM, Keiser K, eds.Pathway of the pulp, 9th edition St Louis, MO:Mosby. Pp.120-32, 2006.

[46] Saunders WP, Chestnutt IG, Saunders EM. "Factors influencing the diagnosis and management of teeth with pulpal and periradicular disease by general dental practioners”, Part 2. Br Dent J, Vol/Issue: 187(10). Pp. 548-54, 1999.

[47] Whithworth JW, Seccombe GV, Shoker K, Steele JG. "Use of rubber dam and irrigant selection in U.K general dental practice”, Int Endod J, Vol/Issue: 33(5). Pp. 435-41, 2000.

[48] Stewardson DA. "Endodontics and new graduates: Part 1, practice vs training”, Eur J Prosthodont Restor Dent, Vol/Issue: 10(3). Pp. 131-7, 2002.

[49] Van Nieuwenhuysen J-P, Aouar M, Dhoore W. "Retreatment or radiographic monitoring in endodontics", Int Endod J, Vol/Issue: 27(2). Pp. 75-81, 1994.

[50] Susini G, Pommel L, Camps J. "Accidental ingestion and aspiration of root canal instruments and other dental foreign bodies in a French population”, Int Endod J, Vol/Issue: 40(8). Pp. 585-9, 2007.

\section{BIOGRAPHIES OF AUTHORS}

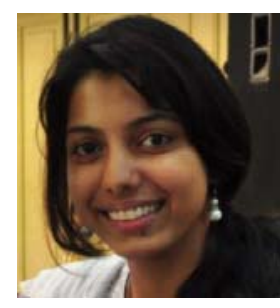

Dr. Priyanka Sriraman is an Intern at Saveetha Dental College, Saveetha University

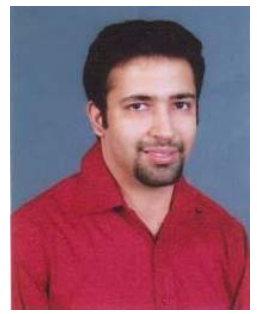

Dr. Prasanna Neelakantan is Assistant Professor of Conservative Dentistry and Endodontics at Saveetha Dental College, Saveetha University. He also heads the undergraduate clinic 6 at Saveetha Dental College. 